\title{
Bovine genital campylobacteriosis: main features and perspectives for diagnosis and control
}

\author{
Cláudia Balzan ${ }^{1 *}$ Rosangela Estel Ziech $^{2}(\mathbb{D})$ Letícia Trevisan Gressler ${ }^{3} \mathbb{C}$ \\ Agueda Palmira Castagna de $\operatorname{Vargas}^{1}\left[{ }^{1}\right.$
}

\footnotetext{
${ }^{1}$ Programa de Pós-graduação em Medicina Veterinária (PPGMV), Departamento de Medicina Veterinária Preventiva, Centro de Ciências Rurais (CCR), Universidade Federal de Santa Maria (UFSM), 97105-900, Santa Maria, RS, Brasil. E-mail: cl.balzan@gmail.com. ${ }^{*}$ Corresponding author.

${ }^{2}$ Médica Veterinária, Prefeitura Dois Vizinhos, Dois Vizinhos, PR, Brasil.

${ }^{3}$ Laboratório de Microbiologia e Doenças Infecciosas, Instituto Federal de Educação, Ciência e Tecnologia Farroupilha (IFFar), Frederico Westphalen, RS, Brasil.
}

\begin{abstract}
Bovine genital campylobacteriosis $(B G C)$ is a venereal disease caused by Campylobacter fetus subsp. venerealis. In countries with large cattle herds, such as Brazil, where the use of natural breeding as a reproductive strategy is a common practice, BGC is considered an important cause of reproductive failure and economic losses. In these cases, the bull is the asymptomatic carrier of the bacterium and the infected females can have infertility and even abortions. The techniques for the diagnosis of C. fetus are isolation in culture medium and identification by biochemical tests, immunofluorescence, immunoenzymatic assays and molecular techniques. Disease control is based on vaccination with bacterins. This review described the epidemiology, etiology, pathogenesis, and advances in the diagnosis and control of BGC. Key words: Campylobacter fetus subsp. venerealis, infertility, venereal disease, beef cattle.
\end{abstract}

Campilobacteriose genital bovina: principais características e perspectivas para o diagnóstico e controle

RESUMO: A campilobacteriose genital bovina (CGB) é uma importante enfermidade de caráter venéreo causada por Campylobacter fetus subsp. venerealis. Em países com grandes rebanhos bovinos, como o Brasil, onde o uso da monta natural como estratégia reprodutiva é uma prática corrente, a CGB é considerada uma importante causa de falhas reprodutivas e perdas economicas. Nestes casos, o touro é o portador assintomático da bactéria e as fêmeas infectadas podem apresentar infertilidade e até mesmo abortos. As técnicas para o diagnóstico de C. fetus são o isolamento em meio de cultura e identificação por testes bioquímicos; imunofluorescência; ensaios imunoenzimáticos e técnicas moleculares. O controle da doença é baseado em vacinação. Neste sentido, esta revisão consiste em uma abordagem sobre a epidemiologia, a etiologia, a patogenia, os avanços no diagnóstico e controle da CGB.

Palavras-chave: Campylobacter fetus subsp. venerealis, infertilidade, doenças venéreas, bovinos de corte.

\section{INTRODUCTION}

Bovinegenitalcampylobacteriosisiscaused by the microaerophilic bacterium Campylobacter fetus subsp. venerealis, a gram-negative rod. This is a venereal disease with worldwide distribution and high incidence in developing countries where natural breeding is widely used for bovine reproduction (MSHELIA et al., 2010), such as in Brazil. The BGC was first diagnosed in Brazil in 1955 in an aborted fetus (RAMOS et al., 1983) and remains in the herds of this country to date. Also, BGC is on a list of notifiable diseases that are significant in international trade in animals or animal products, maintained by the World Organization for Animal Health (OIE,
2017). Published reviews have highlighted the prevalence, epidemiology, diagnosis and/or control of BGC (ALVES et al., 2011; BONDURANT, 2005; CORBEIL et al., 2003; HOFFER, 1981; MICHI et al., 2016; MSHELIA et al., 2007; SILVEIRA et al., 2018). Therefore, facing the woldwide impact of BGC, this review discussed the distribution, etiology, pathogenesis, C. fetus virulence factors, epidemiology, and advances in diagnosis and control of BGC, emphasizing its occurrence in Brazil.

\section{Epidemiology and distribution}

Recent data from the OIE (2019) indicated the presence of BGC in Argentina, Brazil, Colombia, Uruguay, Australia, New Zealand, Ireland, France, 
South Africa, Iran, and Nigeria between January and June 2018. In Nigeria, approximately 520,000 cattle are affected by BGC with a direct loss of 8.5 million dollars due to abortions and low fertility rates (MSHELIA et al., 2012).

In Brazil, BGC is among the most important causes of reproductive failure in beef and dairy farms which use natural breeding (VARGAS et al., 2002; LEAL et al., 2012; MIRANDA, 2005; OLIVEIRA et al., 2015; STYNEN et al., 2003). As shown in table 1 , over the last 23 years, BGC has been reported in all regions of Brazil. There are specific prevalence studies, which usually involve a unique region of a state or diagnostic laboratory data. In Brazil, there are no official surveys, no estimates of losses caused by the disease, and no prediction of an eradication and control program. Moreover, BGC incidence remains understimated due to the absence of systematic diagnosis, which is associated with logistic issues, such as sample collection and shipment, as well as a limited number of laboratories qualified to perform BCG diagnosis (ALVES et al., 2011).

The main risk factor for the spread of BGC is natural breeding (MSHELIA et al., 2012), especially when bulls older than 4 years and without sanitary control for BGC are employed (HOFFER, 1981; BONDURANT, 2005). Even in farms using artificial insemination (AI), the use of bulls after AI is a very common practice (STYNEN et al., 2003). Another risk factor is the use of semen without appropriate antimicrobials (BONDURANT, 2005).

Table 1 - Surveys reporting the prevalence of BGC in Brazil between 1995 and 2018.

\begin{tabular}{|c|c|c|c|c|c|c|}
\hline Study & Year & State & Technique & Sample from & Cattle & $\begin{array}{l}\text { \% positive } \\
\text { animals }\end{array}$ \\
\hline $\begin{array}{l}\text { PELLEGRIN et } \\
\text { al. (2002) }\end{array}$ & 1995-1996 & MS & DFAT & B & Beef & $\begin{array}{c}51.65 \% \\
(171 / 327)\end{array}$ \\
\hline $\begin{array}{l}\text { STYNEN et al. } \\
(2003)\end{array}$ & 1998 & MG & DFAT & $\mathrm{C}$ & Dairy & $25.5 \%(40 / 157)$ \\
\hline $\begin{array}{l}\text { MIRANDA } \\
\text { (2005) }\end{array}$ & 2000 & $\begin{array}{c}\text { BA, GO, MA, } \\
\text { MT, MS, MG, } \\
\text { PA, PR, RS, } \\
\text { RO, SP, TO }\end{array}$ & DFAT & B & Beef & $\begin{array}{c}19.7 \% \\
(224 / 1191)\end{array}$ \\
\hline $\begin{array}{l}\text { ROCHA et al. } \\
\text { (2009) }\end{array}$ & 2009 & RJ & DFAT/I & B & Beef/Dairy & $\begin{array}{c}\text { IFD } 35.9 \% \\
(14 / 39) \\
\text { I } 10.3 \%(4 / 39)\end{array}$ \\
\hline LEAL (2012) & 2009 & $\mathrm{DF}$ & DFAT & $\mathrm{B} / \mathrm{C}$ & $\mathrm{n} / \mathrm{i}$ & $11.1 \%(44 / 398)$ \\
\hline $\begin{array}{l}\text { ZIECH et al. } \\
\text { (2014) }\end{array}$ & 1999-2010 & RS & PCR & $\mathrm{B} / \mathrm{C} / \mathrm{F}$ & Beef/Dairy & $10.9 \%(89 / 816)$ \\
\hline $\begin{array}{l}\text { OLIVEIRA et al. } \\
\text { (2015) }\end{array}$ & 2013 & PE & PCR & $\mathrm{C}$ & Dairy & $1.8 \%(7 / 383)$ \\
\hline $\begin{array}{l}\text { BOTELHO et al. } \\
\text { (2018) }\end{array}$ & 2013 & MG & PCR & B & Beef & $17.5 \%(35 / 200)$ \\
\hline $\begin{array}{l}\text { NASCIMENTO } \\
\text { et al. (2018) }\end{array}$ & 2016 & $\mathrm{AL}$ & PCR & B & Beef & $4.9 \%(8 / 162)$ \\
\hline $\begin{array}{l}\text { FILHO et al., } \\
2018\end{array}$ & 2016 & PB & PCR & $\mathrm{C}$ & Dairy & $7.7 \%(21 / 273)$ \\
\hline $\begin{array}{l}\text { BALZAN, } \\
\text { unpublished data }\end{array}$ & 2011-2018 & RS & $\mathrm{I} / \mathrm{PCR}$ & $\mathrm{B} / \mathrm{C} / \mathrm{F}$ & Beef/Dairy & $8 \%(21 / 261)$ \\
\hline
\end{tabular}

MS: Mato Grosso do Sul; MG: Minas Gerais; BA: Bahia; DF: Distrito Federal; GO: Goiás; MA: Maranhão; MT: Mato Grosso; PA: Pará; PR: Paraná; RS: Rio Grande do Sul; RO: Rondonia; SP: São Paulo; TO: Tocantins; RJ: Rio de Janeiro; PE: Pernambuco; AL: Alagoas; PB: Paraíba. DFAT: Direct Fluorescence Antibody Test; I: Isolation; PCR: Polymerase Chain Reaction (HUM et al., 1997).

B: Bulls; C: Cows; F: fetuses; n/i: no information. 
In herds recently exposed to $\mathrm{BGC}$, the conception rates can be $50 \%$ lower than expected (DEDIE et al., 1982 apud BONDURANT, 2005). The main risk groups are heifers and cows newly introduced in the herd, in which clinical signs are most pronounced due to low levels of immunity (HOFFER, 1981).

\section{Etiology and pathogenesis}

Microorganisms of the genus Campylobacter are gram-negative curved rods 0.2 to $0.5 \mu \mathrm{m}$ diameter, mobile with polar flagella, oxidase positive, and with variable catalase reactions (VAN BERGEN et al., 2005a; QUINN et al., 2011).

Microaerophilic bacteria comprised the genus Campylobacter, which generally require oxygen concentrations between 3 and $15 \%$ and carbon dioxide concentrations from 3 to 5\%. Only a few species are aerotolerant and can grow in the presence of oxygen (HOLT et al., 1994). C. fetus as a pathogen in cattle and sheep and is subdivided into two subspecies, $C$. fetus subsp. fetus and $C$. fetus subsp. venerealis, by habitat characteristics, transmission, clinical manifestations, and laboratory phenotypic identification (VÉRON \& CHATELAIN, 1973). These subspecies are phenotypically differentiated according to HOLT et al. (1994), with tests of tolerance to $1 \%$ glycine and production of hydrogen sulphide $\left(\mathrm{H}_{2} \mathrm{~S}\right)$, with $C$. fetus subsp. fetus returning positive results in both assays, and $C$. fetus subsp. venerealis as negative. C. fetus subsp. venerealis still presents as a biovar, classified by the ability to produce $\mathrm{H}_{2} \mathrm{~S}$ but not $1 \%$ glycine tolerant, and is referred to as $C$. fetus subsp. venerealis biovar intermedius (VÉRON \& CHATELAIN, 1973).

C. fetus subsp. fetus is commensal in the gastrointestinal tract and occasionally causes abortion in sheep and cattle (FLORENT, 1959 apud SKIRROW, 1994); whereas, C. fetus subsp. venerealis is present exclusively in the genital tract of cattle resulting in infertility and abortions, the bacterium being transmitted exclusively by the venereal route (HUM \& QUINN., 1994).

Infection by $C$. fetus subsp. venerealis in bulls is not associated with clinical signs, changes in semen quality, or genital abnormalities (BIER et al., 1977a), and the microorganism persists in the epithelial crypts of the prepuce. Transmission to females occurs during natural mating with infected bulls, or by AI with contaminated semen, when the bacterium is distributed through the mucosa of the vagina, cervix, uterus, and uterine tubes (BONDURANT, 2005). Approximately one third of infected cows become carriers (QUINN et al., 2011), and other males may be contaminated by mating with sick or carrier cows (HOFFER, 1981).

C. fetus subsp. venerealis persistently colonizes the preputial cavity of the bull, preventing it from elaborating an effective immune response, and thus the animal remains as an asymptomatic carrier (VAN BERGEN, 2005a). Bulls older than 4 years of age are more likely to be carriers because they have deeper crypts where microorganisms find favorable conditions and safe harbor (SAMUELSON \& WINTER, 1966). Infection can persist for months to years in older bulls (BIER et al., 1977a).

After coitus, an ascending infection is established in females, and in 12 to 14 days the microorganism is distributed from the vagina/ cervix to the uterine horns (BONDURANT, 2005; CORBEIL, 1999; YAEGER \& HOLLERY, 2007). Then, development of endometritis and salpingitis occur during progestational phase of the estrous cycle, when both the amount and activity of neutrophils decline (VAN BERGEN, 2005a; QUINN et al., 2011). C. fetus subsp. venerealis does not interfere with the process of fertilization and initial embryonic development. However, endometritis prevents implantation of the embryo (HOFFER, 1981), followed by early embryonic death. After uterine invasion, in a period of 3 to 6 months, the cow can remain infertile and a source of infection (VAN BERGEN, 2005a); and subsequently, acquired immunity is developed.

The predominant immunity in $C$. fetus infected animals is local (CORBEIL et al., 1974), with reported differences between males and females. In females, antibody production in the vagina and uterus begins 40 to 60 days after infection (CORBEIL et al., 1974).

In preputial secretions of healthy bulls, IgG predominates in abundance, followed by IgA (BIER et al., 1977b), and in bulls infected with $C$. fetus subsp. venerealis, the serum antibody response is undetectable (VASQUEZ et al., 1983). Infiltration of lymphocytes and subepithelial plasma cells is similar in the prepuce and penis of infected and uninfected bulls (BIER et al., 1977b; SAMUELSON \& WINTER, 1966). In the vagina, IgA predominates, which may limit the spread of the infection; IgGs are produced in the uterus and these opsonize the pathogenic organisms, facilitating phagocytosis by neutrophils and mononuclear cells (CORBEIL, 1999; table 2). As BGC is caused by an extracellular pathogen, it would be expected to elicit predominantly a humoral immune response (CORBEIL et al., 
Table 2 - Immunity to Campylobacter fetus subsp. venerealis. Adapted from CORBEIL (1999).

\begin{tabular}{lccc}
\hline & & & \\
\hline & Uterus & Vagina & Clearance \\
Systemic immunization & $\operatorname{IgG}$ & $\operatorname{IgG}$ & Quick Uterus and vagina \\
Natural immunity (Local) & $\operatorname{IgG}$ & $\operatorname{IgA}$ & Slower - uterus then vagina \\
\hline
\end{tabular}

1974), likely causing short duration of immunity to infectious agent (BONDURANT, 2005).

The presence of carrier cows is due to the evasion of local immune responses, which CORBEIL (1999) attributes to factors such as the relative lack of spontaneous $\operatorname{IgG}$ response in the vagina, possible blockage of vaginal $\mathrm{IgG}$ effects by $\operatorname{IgA}$ binding microorganisms, and by variation of surface antigens of the microorganism against local immune responses. In bulls, infections are persistent and result in asymptomatic carrier animals, indicating that immunity during inflammation does not eliminate mucosal microorganisms (COBO et al., 2011). Nevertheless, according to TIZARD (2015), C. fetus infections are associated with the presence of several mononuclear cell types, as well as late cutaneous reactions (type IV hypersensitivity), so that cellmediated immunity also participates in resistance to infection. Once the prolonged vaginal carrier status has been determined for C. fetus subsp. venerealis, the cow remains with the vaginal infection, whereas the uterus is free of infection (BONDURANT, 2005). This allows for the return of the cow's fertility in many cases, and may last up to 2 years in the absence of antigenic stimulation (CORBEIL et al., 1974). In bulls, persistence of the bacteria in the lower genital tract is also attributed to evasion of immune responses (VARGAS et al., 2002; CORBEIL, 1975).

\section{Genes and virulence factors}

Complete genomic sequencing of $C$. fetus is relatively recent. In 2006, the first complete and closed genome of $C$. fetus was made available by The Institute for Genomic Research (TIGR, USA, 2006), and this was the 82-40 strain isolated from an individual in the United States and later identified as C. fetus subsp. fetus, with a $1.77 \mathrm{Mpb}$ genome and approximately 1,820 predicted genes. The first sequenced genome of $C$. fetus subsp. venerealis was published by MOOLHUIJZEN et al. (2009) as a not assembled genome consisting of multiple contigs of the Azul-94 strain, which was isolated from an aborted bovine fetus in Argentina.
Since then, genomic studies of $C$. fetus have expanded. This can be verified by queries on databases of DNA sequences, such as GenBank ${ }^{\circledR}$, where currently there are 74 genomes of $C$. fetus published, including 11 complete genomes (IRAOLA et al., 2017; KIENESBERGER et al., 2014; VAN DER GRAAF-VAN BLOOIS et al., 2014; WANG et al., 2015). Whole genome sequencing can be used to differentiate the mammal-associated $C$. fetus strains based on their core genomes (VAN DER GRAAFVAN BLOOIS et al., 2014) and provides data on strains prevalent worldwide. Thus, genomic research in C. fetus is very important in providing new information about the species and its subspecies, to enable scientific advances regarding their origins and hosts, and for the correct identification of strains.

Current research on species of Campylobacter concentrates on total genomic analysis for the identification of virulence genes and characteristics that contribute to the pathogenicity differences among subspecies (FOUTS et al., 2005; MOOLHUIJZEN et al., 2009; ALI et al., 2012; VAN DER GRAAF-VAN BLOOIS et al., 2016; IRAOLA et al., 2017; GILBERT et al., 2018). In the C. fetus subespecies these virulence factors were clearly identified as classes of genes encoding proteins (MOOLHUIJZEN et al., 2009), such as surface polypeptides involved in bacterial adherence, motility, toxin production and resistance, and regulatory and secretion systems.

Linkage between bacterial pathogens and epithelial cells is a prerequisite for invasion of host cells and subsequent translocation to the deeper layers of the mucosa. The spiral shape of the cell and the corkscrew-like motility conferred by the flagella of $C$. fetus are needed to colonize and cross the mucus barrier that covers the vaginal epithelium (SPRENGER et al., 2012). In addition, the flagellum is an important adhesin of C. jejuni and may have a similar function in C. fetus. Genomes of the two subspecies of $C$. fetus harbor homologs of adhesin PEB1, which is an outer membrane protein (OMP) and important in adherence to epithelial cells 
(SPRENGER et al., 2012). Therefore, motility and adhesion capacity of host cells play fundamental roles in the diseases caused by bacteria belonging to the genus Campylobacter.

A genomic island encoding a type IV secretion system integrated into the genome of $C$. fetus subsp. venerealis was identified, and it was believed that this genomic island was a determinant for the tropism of this subspecies in the bovine genital tract (GORKIEWICZ et al., 2010). However, phylogenetic analyses between genomes of strains of the two subspecies of $C$. fetus showed that this coding region involving the type IV secretion system exists in both subspecies as an element acquired from different donors and contains fic $(\mathrm{n}=4)$ and virD4 $(\mathrm{n}$ $=10)$ genes (VAN DER GRAAF-VAN BLOOIS et al., 2016). In other research, SPRENGER et al. (2017) have demonstrated that $f i c$ genes predominate and are strongly conserved in C. fetus subsp. venerealis, and Fic proteins are related to changes from the normal to the static metabolic states, which assists in the maintenance of the bacterium for long periods in the host, even under stressful conditions.

Several bacteria, including Escherichia coli and Shigella spp., produce Cytolethal distending toxin (CDT). Among Campylobacter strains, the $c d t$ gene cluster is distributed universally and is well conserved, particularly in C. jejuni, C. coli, and C. fetus (ASAKURA et al., 2007). In $C$. jejuni, CDT protein is recognized for causing damage to the DNA of the host and tissue necrosis (JOENS et al., 2011), presenting as a potential virulence factor also in C. fetus.

The lipopolysaccharide (LPS) of C. fetus is typical of gram-negative bacteria. It has a lipid fraction, denominated lipid $\mathrm{A}$, and a polysaccharide fraction, with a central oligosaccharide and an "O" antigen (MORAN et al., 1996). In C. fetus, lipid A has low biological activity compared to other Enterobacteriaceae family members, and this is associated with persistent colonization of the host (BLASER \& ENGBERG, 2008). Variation in O antigen is the basis of a serotyping scheme for $C$. fetus, and two main serotypes, denominated $\mathrm{A}$ and $\mathrm{B}$, are recognized (VAN BERGEN et al., 2005a; DWORKIN et al., 1995a; PEREZ-PEREZ et al., 1986; TU et al., 2004). C. fetus subsp. fetus contains serotypes A and B, whereas C. fetus subsp. venerealis has only serotype A.

C. fetus has a protein structure covering the outer membrane. MCCOY et al. (1975) were the first to describe the presence of a microcapsule called the S layer, formed by protein subunit arrays known as surface array proteins (SAPs), and recognized as important in the pathogenesis of BGC (MCCOY et al., 1975; FAGAN \& FAIRWEATHER, 2014; WINTER et al., 1978) because, these SAPs are responsible for the resistance of this microorganism to bactericidal and phagocytic activities of the host (MCCOY et al., 1975; RAY et al., 2000). Their superficial location suggested that they may be an important mediator in interactions with the host (BLASER \& GOTSCHLICH, 1990), and in persistence of the pathogen in the reproductive tract (CORBEIL et al., 1975).

A particular aspect of the surface proteins in $C$. fetus is the fact that a single bacterium can produce up to three proteins, with molecular mass ranging from 97 to $149 \mathrm{kDa}$ and usually one of these being dominant (DUBREUIL et al., 1990; DWORKIN et al., 1995a; DWORKIN et al., 1995b; FUJIMOTO, 1991; PEI et al., 1988, VARGAS et al., 2002). During infection, extensive high frequency chromosomal rearrangements occurred in DNA, and this results in the modification of dominant epitopes during persistence of the bacteria in the genital tract (GARCIA et al., 1995; WANG et al., 1993). Thus, this evidence showed the importance of surface proteins for C. fetus subsp. venerealis; and consequently, for the maintenance of BGC infection. Because of this, such proteins are potential candidates for the development of serological diagnostic methods, and according to PEI et al. (1988), for use in vaccines.

\section{Diagnosis of $B G C$}

The subspecies of C. fetus showed different adaptations to host tissues. However, at the genetic level they are practically indistinguishable (MOOLHUIJZEN et al., 2009). Sequence alignment reveals that the genotypes of $C$. fetus subspecies are highly homologous, with $92.9 \%$ average identity (KIENESBERGER et al., 2014).

The materials for laboratory diagnosis of BGC from suspect animals include samples of prepucial smegma and semen in bulls, and female specimens of cervicovaginal mucus (OIE, 2017). In addition, samples of aborted fetuses and placenta can be collected. The diagnosis of BGC is at the herd level, so it is not considered for isolated cases, but an epidemiological profile of the herd based on the history of clinical manifestations compatible with this disease and analysis of reproductive rates, to be confirmed with laboratory assays.

In females, cervicovaginal mucus can be collected with an insemination pipette or absorbent pad (OIE, 2017; STYNEN et al., 2003). Preputial samples from bulls can be obtained by scraping or washing with sterile saline (OIE, 2017). An important 
aspect to be observed is the maintenance of bulls in sexual rest for 7 to 15 days before harvesting the material to increase the sensitivity of the diagnosis (SKIRROW \& BONDURANT, 1988). Moreover, the OIE (2017) indicated the use of transport media to maintain viability in samples that will not be processed in the laboratory on the same day of collection. Enriched and selective transport media (Lander, Foley and Clark, for example) are suitable for transporting the samples, and when these media are not available, the collected material should be placed in a sterile recipient container (temperature 4-10 ${ }^{\circ} \mathrm{C}$ ) and protected from light.

Techniques for the diagnosis of $C$. fetus involve the isolation and identification of the infectious agent, immunofluorescence, immunoenzymatic tests, and molecular identification (OIE, 2017). The use of two combined techniques to obtain a result is preferred to give reliability to the result of the diagnosis, but several laboratories do not apply or do not perform the techniques correctly (VAN BERGEN et al., 2005a).

\section{Isolation and identification of C. fetus}

The isolation and identification of $C$. fetus by microbiological culture is considered the standard and confirmatory test for diagnosis of infection (BROOKS et al., 2004) and is a suitable assay for certifying individual animals prior to movement (OIE, 2017). However, the same depends on the sample quality, the way it is sent to the laboratory, and the viability of the microorganisms. Campylobacter species are microaerophilic and C. fetus grows fastidiously, requiring strictly atmospheric conditions for cultivation, including selective and enrichment media (QUINN et al., 2011).

The discrimination of subspecies isolates is based on colony morphology on blood agar plates, certain biochemical properties, and antimicrobial susceptibility (QUINN et al., 2011). Gram staining, catalase test, and oxidase activity are the assays most frequently used in diagnostic laboratories, followed by motility testing (VAN BERGEN et al., 2005a). In addition, the differentiation of $C$. fetus subspecies is carried out mainly by antimicrobial susceptibility tests using cefalotin and nalidixic acid (HOLT et al., 1994), and by the evaluation of biochemical characteristics. Moreover, growth at $25^{\circ} \mathrm{C}$ and $42^{\circ} \mathrm{C}$ in the presence of $3.5 \%$ sodium chloride, $\mathrm{H}_{2} \mathrm{~S}$ production, and $1 \%$ glycine tolerance testing (HOLT et al., 1994) are used, the latter being the standard assay for subspecies differentiation (VAN BERGEN et al., 2005a).
However, researchers report doubts concerning differentiation by the phenotypic tests mentioned above (VAN DER GRAAF-VAN BLOOIS et al., 2014). First, C. fetus subsp. venerealis biovar intermedius is able to produce $\mathrm{H}_{2} \mathrm{~S}$ (a characteristic previously attributed only to $C$. fetus subsp. fetus). In terms of glycine tolerance, CHANG \& OGG (1970) have shown that this characteristic can be influenced by transduction of this phenotypic characteristic by bacteriophages. In addition, antimicrobial resistance can be acquired through transduction or mutations (CHANG \& OGG, 1970; SALAMA et al., 1992).

The procedures for isolation and identification of C. fetus are laborious and require special culture media and atmospheric conditions, restricting the number of laboratories able to carry out diagnosis of this microorganism. In addition, inconsistencies between phenotypic and genomic characteristics of $C$. fetus samples revealed in recent research (VAN DER GRAAF-VAN BLOOIS et al., 2014) have stimulated a critical evaluation of the clinical relevance of identification of $C$. fetus subspecies using phenotypic tests. Therefore, some techniques such as fluorescence antibody test (FAT) and polymerase chain reaction (PCR) are also used for the detection of BGC, combined with microbiological isolation (VAN BERGEN et al. , 2005a).

In Brazil, only one published research report used microbiological isolation in combination with another technique. The study of ROCHA et al. (2009) investigated the presence of C. fetus in samples from bulls on dairy and beef farms in the region of the Médio Paraíba, state of Rio de Janeiro and used microbiological isolation combined with direct immunofluorescence (DIF) testing. By DIF, ROCHA et al. (2009) confirmed the presence of C. fetus in $35.9 \%(14 / 30)$ of samples, and in the microbiological culture and biochemical tests, obtained $10.3 \%$ (4/30) positivity for C. fetus subsp. venerealis (Table 1).

For routine diagnostic activities of the Laboratory of Bacteriology of the Universidade Federal of Santa Maria, microbiological culture combined with PCR was established (HUM et al., 1997). From 2011 to 2018, 261 samples of beef and dairy cattle from 43 breeding farms in Rio Grande do Sul state were analyzed. Prepural aspirate $(n=147)$, cervical mucus $(n=108)$ and fetal abomasal content $(n$ $=6$ ) were analyzed. The presence of samples positive for $C$. fetus in this period was $2.72 \%(4 / 147)$ in bulls, $14.82 \%(16 / 108)$ in cows, and $16.66 \%(1 / 6)$ in fetuses. For farms, $23.25 \%(10 / 43)$ had at least one $C$. fetus positive animal in $42.86 \%(9 / 21)$ of the municipalities analyzed (BALZAN, unpublished data). 


\section{Fluorescent Antibody Test (FAT)}

Immunofluorescence tests can be applied

for direct diagnosis of microorganism in samples, or to confirm the identification of microorganisms after isolation (VAN BERGEN et al., 2005a; OIE, 2017). FATs are generally used as a screening test for preputial samples (CIPOLLA et al., 2001).

In a study by FIGUEIREDO et al. (2002), the direct FAT (DFAT) demonstrated good detection limits $(100 \mathrm{CFU} / \mathrm{mL})$ in preputial washes, with $92.59 \%$ sensitivity and $88.89 \%$ specificity. These results demonstrated the use of DFATs as an important support technique for the control of BGC. In Argentina, due to the implementation of a national health plan to control venereal diseases in cattle from 1983, there are approximately 30 laboratories that mainly use DFAT assays to diagnose BGC from bull samples (CIPOLLA et al., 2001). This health plan was successful in controlling the disease, given the reduction in the percentage of BGC in herds of beef cattle from approximately $50 \%$ in 1983 to $15-18 \%$ in the period 1997-1999 (CIPOLLA et al., 2001).

The immunofluorescence test was not widely evaluated and the reported problems were false-positive results due to non-specific fluorescence and inability to differentiate $C$. fetus subspecies (SILVEIRA et al., 2018), with low availability of conjugate. In addition, technicians must be trained and experienced so that performance of the test is not impaired by subjectivity (FIGUEIREDO et al., 2002).

In Brazil, DFAT was widely used in surveys of the occurrence of $C$. fetus in several regions (table 1) until 2009 and obtained high rates of positivity. Nowadays, the commercial unavailability of conjugates makes the use of the technique restricted to certain research laboratories producing these inputs.

\section{Molecular identification of C. fetus}

The amplified fragment length polymorphism (AFLP) (WAGENAAR et al., 2001) and multilocus sequence typing (MLST) (VAN BERGEN et al., 2005c) methods were firstly recommended to differentiate the two subspecies, fetus and venerealis, but these tests are laborious, impractical for routine use and, according to VAN DER GRAAF-VAN BLOOIS et al. (2013) and IRAOLA et al. (2017), are not fully reliable for $C$. fetus subspecies differentiation.

A practical platform for BGC diagnosis is the PCR technique, since this assay is rapid, simple, and reliable. Several PCR assays have been developed to identify C. fetus (ABRIL et al., 2007;
VAN BERGEN et al., 2005b; HUM et al., 1997; MCMILLEN et al., 2006; TU et al., 2005; WANG et al., 2002). The evaluation of these several PCRs (VAN DER GRAAF-VAN BLOOIS et al., 2013) showed that only those of HUM et al. (1997) and ABRIL et al. (2007) are valid for identification of $C$. fetus in terms of sensitivity and specificity; however, both techniques require the isolation of bacteria or culture of samples in medium for enrichment for DNA extraction.

Further, multiplex PCR assays (HUM et al., 1997) and real-time PCR with specific probes (MCMILLEN et al., 2006), are able to identify C. fetus to the species level only. The OIE (2017) recommendation is that a PCR assay to identify C. fetus isolates reliably to subspecies level is not available and that researchers need to be careful and critical when publishing results at the (unreliable) subspecies level.

CHABAN et al. (2012) used the conventional PCR primers of HUM et al. (1997) applied to a quantitative real-time PCR platform for direct processing of preputial samples, aiming to improve the original assay, which had low analytical sensitivity. The test developed proved to be sensitive and low cost; however, the processing of preputial samples for direct detection is as laborious as for conventional PCR, or for isolation of bacteria.

To allow differentiation of $C$. fetus subspecies, MCGOLDRICK et al. (2013) adapted some PCR methods already published (CASADÉMONT et al., 1998; HUM et al., 1997) for quantitative PCR (qPCR), and reported a sensitivity of $98.7 \%$ and specificity of $99.8 \%$ for C. fetus subsp. venerealis identification, and this technique has been approved for routine subspecies characterization when there are doubts in the OIE (2017) recommended trials. VAN DER GRAAFVAN BLOOIS et al. (2013) developed a qPCR assay with $100 \%$ sensitivity and $100 \%$ specificity for the detection of $C$. fetus, but did not meet the objective of differentiating the subspecies of $C$. fetus.

Recently, papers published in Brazil (Table 1) used the conventional PCR technique described by HUM et al. (1997). Some of this research (FILHO et al., 2018; NASCIMENTO et al., 2018; OLIVEIRA et al., 2015) used only a pair of primers specific for $C$. fetus subsp. venerealis identification (VENS - parA gene), which is not recommended. As evaluated by VAN DER GRAAFVAN BLOOIS et al. (2013), the technique of HUM et al. (1997) has $100 \%$ sensitivity and $100 \%$ specificity for the detection of C. fetus, and 58\% sensitivity and 
$83 \%$ specificity for $C$. fetus subsp. venerealis, so it is reliable for species identification only.

Therefore, a critical evaluation of publications regarding available PCR techniques has been recommended for implementation of such techniques in a laboratory for the diagnosis of Campylobacter fetus.

\section{Enzyme-linked immunosorbent assay (ELISA)}

In the diagnosis of BGC, ELISA could be used for evaluating herd immunity, but is not acceptable for diagnosis of the infection in individual animals, and cannot differentiate between infections caused by the two subspecies of $C$. fetus that causes disease in ruminants (OIE, 2017). In Brazil, currently, reports on the use of ELISA to diagnose BGC are unavailable.

Previous studies to improve BGC diagnosis have used ELISA to detect IgA in samples such as cervical mucus, preputial washings, and contents of aborted fetuses (DEVENISH et al., 2005; HEWSON et al., 1985; MSHELIA et al., 2010; PELLEGRIN et al., 2011; HUM \& QUINN, 1994). These IgA antibodies were chosen because they persist for longer and their concentration remains constant in the genital tract for many months (HUM \& QUINN, 1994). However, problems with sensitivity and specificity (false-positive/-negative) were reported by HUM \& QUINN (1994) in an ELISA for IgA detection, in which the vaginal mucus of bovine females with suspicted $C$. fetus infection was used.

BROOKS et al. (2004) and DEVENISH et al. (2005) used monoclonal antibodies against C. fetus LPS antigen in capture ELISA, but did not obtain a satisfactory detection limit $\left(10^{5}\right.$ to $10^{7}$ $\mathrm{CFU} / \mathrm{mL}$ ), making this technique using monoclonal antibodies viable only after a period of enrichment of the sample for 4 to 5 days. Antigens used to sensitize plaques were whole bacteria or obtained by acid extraction from $C$. fetus cultures using glycine buffer. However, these samples are not easy to obtain and there are false-positive results. The main problems with ELISA techniques developed are limitations in sensitivity and/or specificity.

ZHAO et al. (2010) developed and evaluated a highly specific $(94.3 \%)$ and sensitive $(88.6 \%)$ indirect ELISA for the detection of IgG antibodies against $C$. fetus in bovine sera by validating as antigen the recombinant proteins SapA-N and SapA-C. These researchers were successful in choosing the N-terminal region of SapA protein from a field strain, noting their immunodominance and the presence of multiple antigenic epitopes, as reported by WANG et al. (1993).

\section{Differential diagnosis}

Other agents transmitted by sexual contact cause reproductive problems in cattle herds and should be considered for a correct diagnosis. The diagnosis of reproductive disease is mostly performed with serum samples, but when herd history reveals infertility, samples such as preputial smegma, semen, fetal fluid, placenta, and vaginal discharge can provide a definitive diagnosis (GIVENS, 2006).

The protozoan Tritrichomonas fetus, responsible for bovine genital trichomoniasis, causes disease with aspects similar to BGC and should be investigated as a differential diagnosis (BONDURANT, 2005). Trichomoniasis is usually diagnosed using culture and/or PCR, and the sample types are the same for BGC diagnosis (MICHI et al., 2016). In addition, BONDURANT (2005) and GIVENS (2018) cite Haemophilus somnus, Ureaplasma, and other Mycoplasmas and in some special conditions, Leptospira spp., Brucella abortus, and viral diseases such as Bovine Viral Diarrhea (BVD) and Infectious Bovine Rhinotracheitis (IBR) causing infertility and/or abortions in cattle herds. In these cases, clinical signs and epidemiological characteristics should be taken into account, along with the results of laboratory tests (GIVENS, 2006).

Another microorganism very similar to Campylobacter in microbiological cultures is Arcobacter sp. (ETONSI, 2013). This species growth in aerobiosis and it is enough to undo the mistake, as well as the use of selective broth to enrichment can eliminate this bacterium. The Arcobacter sp.; although, isolated from bovine abortion cases (FERNÁNDEZ et al., 1995; NEILL et al., 1985), was also recovered from preputial bovine washes, and from vaginal swabs of cows without observable reproductive problems (KABEYA et al., 2004). Therefore, in situations of microbiological culture of samples from animals suspected of BGC infection, Arcobacter spp. should be included for differential diagnosis.

\section{Prevention and control}

The control of the disease in herds is carried out with the implementation of AI programs, avoiding the use of bulls (BONDURANT, 2005), and mainly with the introduction of vaccination in bulls and cows. The practice of discarding bulls bearing $C$. fetus subsp. venerealis, according to PELLEGRIN et al. (2002), as well as the implementation of a limited breding season (60 to 90 days), discarding of nonpregnant females at the end of the breeding season, and sexual rest for 3 to 4 cycles for recovery of females, are also measures recommended for BGC control. 
Vaccination is quite effective in preventing the recurrence of estrus and abortion caused by $C$. fetus subsp. venerealis, according to BONDURANT (2005). Commercial vaccines used for the control and prophylaxis of BGC are composed of bacterins with adjuvants, given as subcutaneous or intramuscular injections. There are reports of good efficacy when administered to females, inducing at least partial protection against experimental genital infection (COBO et al., 2004). In herds infected with C. fetus subsp. venerealis, reproductive age females should be vaccinated annually, approximately 30 days before the start of breeding (BONDURANT, 2005). In the case of first vaccination, heifers and cows should receive two doses, at approximately 60 and 30 days, respectively, before the beginning of the breeding season. Vaccination alone is often not considered sufficient to manage an outbreak of BGC, and in bulls it is necessary to test and cull positive animals (ERICKSON et al., 2017).

When comparing the efficacy of 10 commercial vaccines for the prevention of abortion following exposure to $C$. fetus, BRYNER et al. (1988) reported 0 to $89 \%$ in efficiency. These authors reported deficiencies in immune responses to some commercial vaccines, suggesting that the percentage of protection that a vaccine offers is directly proportional to the bacterial mass used, and that immunogenicity of the samples used in the vaccine or type of adjuvant used may arise.

BGC positive cows and bulls can be treated. Cows are not usually treated, and after a few months, can eliminate the infection and return to estrus. Decisions regarding the treatment of bulls should be evaluated taking into consideration the age and value of the animal, since treatment incurs some costs and the animals will need to be managed for several days. There are reports of the use of topical and systemic antimicrobial treatments, with variable results. The tested antimicrobials included streptomycin, dimetridazole chlorhydrate, and oxytetracycline (CAMPERO et al., 1993; ERICKSON et al., 2017). ERICKSON et al. (2017) tested a combination of antimicrobial treatment with injectable oxytetracycline and vaccination with two doses of a monovalent oil-based $C$. fetus subsp. venerealis commercial vaccine in BGC-positive bulls. Two treatments with long-acting oxytetracycline at label doses and a commercial monovalent bacterin did not eliminate BGC in all study bulls. Therefore, this is not recommended as an effective management strategy. However, due to the antimicrobial resistance reported in the last decades and because of legislation in some countries, treatment must be carried out observing the legislation surrounding antimicrobial use in livestock production, and on the recommendation of a veterinarian.

\section{CONCLUSIONS}

BGC is a relevant disease because of its clinical presentation, which causes large economic losses. Published prevalence studies and a survey carried out involving diagnosis of the disease in LABAC/UFSM affirmed that the disease affects cattle herds in several regions of Brazil, and that the losses are underestimated. BGC diagnosis is laborious due to the culture characteristics of Campylobacter and the limitations of other techniques. In addition, there are no projections for disease control and eradication programs at either regional or national levels. Further research aimed to optimize the diagnosis of BGC using molecular techniques could facilitate the establishment of results regarding occurrence and; consequently, taking preventive measures at herd level. Finally, the use of combined diagnostic methods is essential to ensure reliable results.

\section{ACKNOWLEDGEMENTS}

This study was finnanced in part by the Coordenação de Aperfeiçoamento de Pessoal de Nível Superior (CAPES) (finance code 001 and scholarship 88881.135832/2016-01/PDSE) and by Fundação de Amparo à Pesquisa do Estado do Rio Grande do Sul (FAPERGS).

\section{DECLARATION OF CONFLICTS OF INTERESTS}

The authors declare no conflict of interest. The founding sponsors had no role in the design of the study; in the collection, analyses, or interpretation of data; in the writing of the manuscript, and in the decision to publish the results.

\section{AUTHORS' CONTRIBUTIONS}

The authors contributed equally to the manuscript.

\section{REFERENCES}

ABRIL, C. et al. Discovery of insertion element IS Cfe1: A new tool for Campylobacter fetus subspecies differentiation. Clinical Microbiology and Infection, v.13, n.10, p.9931000, 2007. Available from: <https://www.ncbi.nlm.nih.gov/ pubmed/17697006>. Accessed: Nov. 12, 2016. doi: 10.1111/j.14690691.2007.01787.x.

ALI, A. et al. Campylobacter fetus subspecies: Comparative genomics and prediction of potential virulence targets. Gene,v. 508, n.2, p.145-156, 2012. Available from: <https:/www.ncbi. 
nlm.nih.gov/pubmed/22890137>. Accessed: Jan. 25, 2018. doi: 10.1016/j.gene.2012.07.070.

ALVES, T. M. et al. Campilobacteriose genital bovina e tricomonose genital bovina: Epidemiologia, diagnóstico e controle. Pesquisa Veterinaria Brasileira, v.31, n.4, p.336-344, 2001. Available from: <http://www.scielo.br/pdf/pvb/v31n4/ a11v31n4.pdf>. Accessed: Oct. 05, 2015. doi: 10.1590/S0100736X2011000400011.

ASAKURA, M. et al. Comparative analysis of cytolethal distending toxin (cdt) genes among Campylobacter jejuni, $C$. coli and C. fetus strains. Microbial Pathogenesis, v.42, n.5-6, p. 174-183, 2007. Available from: <https://www.ncbi.nlm.nih. gov/pubmed/17353111>. Accessed: Jun. 10, 2018. doi: 10.1016/j. micpath.2007.01.005.

BIER, P. J. et al. Experimental infections with Campylobacter fetus in bulls of different ages. Veterinary Microbiology, v.2, p.13-27, 1977a. Available from: <https://www.sciencedirect.com/science/ article/pii/0378113577900281>. Accessed: Jun. 02, 2015. doi: 10.1016/0378-1135(77)90028-1.

BIER, P. J. et al. Measurement of immunoglobulins in reproductive tract fluids of bulls. Veterinary Microbiology, v.2, n.1, p.111, 1977b. Available from: <https://www.sciencedirect.com/ science/.../pii/037811357790027X > . Accessed Jun. 02, 2015. doi: 10.1016/0378-1135(77)90027-X.

BLASER, M. J.; GOTSCHLICH, E. C. Surface Array Protein of Campylobacter fetus. The Journal of Biological Chemistry v.265, n.24, p.14529-14535, 1990. Available from: <http://www. jbc.org/content/265/24/14529.full.pdf>. Accessed Jun. 02, 2012.

BLASER M.J.; ENGBERG J. Clinical aspects of Campylobacter jejuni and Campylobacter coli infections. In: Nachamkin I., Blaser J.M., editors. Campylobacter. 3rd ed. American Society for Microbiology (ASM) Press; Washington DC, USA: 2008. pp. 99-121.

BONDURANT, R. H. Venereal diseases of cattle: Natural history, diagnosis, and the role of vaccines in their control. Veterinary Clinics of North America - Food Animal Practice, v.21, n.2, p.383-408, 2005. Available from: <http://www.sciencedirect. com/science/article/pii/S0749072005000320>. Accessed Nov. 10, 2012. doi: 10.1016/j.cvfa.2005.03.002.

BROOKS, B. W. et al. Evaluation of a monoclonal antibodybased enzyme-linked immunosorbent assay for detection of Campylobacter fetus in bovine preputial washing and vaginal mucus samples. Veterinary Microbiology, v.103, n.1-2, p.77-84, 2004. Available from: <http://www.sciencedirect.com/science/ article/pii/S0378113504002640>. Accessed. Dec. 10, 2014. doi: 10.1016/j.vetmic.2004.07.008

CAMPERO, C. M. et al. Tratamientos sistemicos en toros con infeccion genital a Campylobacter fetus subsp. fetus. Veterinaria Argentina, v. 10, p. 303-309, 1993.

CASADÉMONT, I. et al. Cloning of a sapB homologue (sapB2) encoding a putative $112-\mathrm{kDa}$ Campylobacter fetus S-layer protein and its use for identification and molecular genotyping. FEMS Immunology and Medical Microbiology, v.21, n.4, p.269-281, 1998. Available from: <https:/www.ncbi.nlm.nih.gov/ pubmed/9752999>. Accessed: Jun. 10, 2012. doi: 10.1016/S09288244(98)00081-9.
CHABAN, B. et al. Evaluation of a Campylobacter fetus subspecies venerealis real-time quantitative polymerase chain reaction for direct analysis of bovine preputial samples. Canadian Journal of Veterinary Research, v.76, n.3, p.166-173, 2012. Available from: $<$ https://www.ncbi.nlm.nih.gov/pmc/articles/PMC3384278/>. Accessed: Dec. 17, 2014.

CHANG, W.; OGG, J. E. Transduction in Vibrio fetus. American Journal of Veterinary Research, v.31, p.919-924, 1970. Available from: $\quad<$ https://www.ncbi.nlm.nih.gov/pubmed/5442454>. Accessed: Nov. 10, 2016.

CIPOLLA, A. et al. Campylobacter fetus diagnosis: Direct immunofluorescence comparing chicken IgY and rabbit IgG conjugates. Altex-Alternativen $\mathrm{Zu}$ Tierexperimenten, v.18, n.3, p.165-170, 2001. Available from:<www.ncbi.nlm.nih.gov/ pubmed/11565050>. Accessed: Sept. 15, 2012.

COBO, E. R. et al. Immunization in heifers with dual vaccines containing Tritrichomonas foetus and Campylobacter fetus antigens using systemic and mucosal routes. Theriogenology, v.62, n.8, p.1367-1382, 2004. Available from: <http://www.sciencedirect. com/science/article/pii/ S0165037811000404>. Accessed: Dec. 17, 2014. doi: 10.1016/j.theriogenology.2003.12.034.

COBO, E. R. et al. Immunity to infections in the lower genital tract of bulls. Journal of Reproductive Immunology, v. 89, n. 1, p. 55-61, 2011. Available from: <https://www.ncbi.nlm.nih. gov/pubmed/21474188>. Accessed: Nov. 25, 2016. doi: 10.1016/j. jri.2011.02.002.

CORBEIL, L. B. et al. Bovine venereal vibriosis: variations in immunoglobulin class of antibodies in genital secretions and serum. Infection and Immunity, v.10, n.5, p.1084-1090, 1974.

CORBEIL, L. B. et al. Bovine venereal vibriosis: antigenic variation of the bacterium during infection. Infection and Immunity, v.11, n.2, p.240-244, 1975.

CORBEIL, L.B. et al. Immunization and diagnosis in bovine reprodutive tract infections. Advances in Veterinary Medicine, v.41, p.217-239, 1999. Available from: <www.ncbi.nlm.nih.gov/ pubmed/9890019>. Accessed Nov. 25, 2016.

CORBEIL, L. B. et al. Vaccines against sexually transmitted diseases. Reproductive Biology and Endocrinology, v.1, n.118, p.1-6, 2003. Available from: <http://www.rbej.com/ content/1/1/118>. Accessed Oct. 10, 2016. doi: 10.1186/14777827-1-118.

DEVENISH, J. et al. Validation of a monoclonal antibody-based capture enzyme-linked immunosorbent assay for detection of Campylobacter fetus. Clinical Diagnostics and Laboratory Immunology, v.12, n.11, p.1261-1268, 2005. Available from: $<$ http://www.ncbi.nlm.nih.gov/entrez/query.fcgi?cmd=Retrieve \&d $\mathrm{b}=$ PubMed\&dopt $=$ Citation\&list_uids $=16275938>$. Accessed Oct. 15 2016. doi: 10.1128/CDLI.12.11.1261-1268.2005.

DUBREUIL, J. D. et al. Antigenic differences among Campylobacter fetus S-layer proteins. Journal of Bacteriology, v.172, n.9, p.5035-5043, 1990. Available from: <http://jb.asm.org/ content/172/9/5035.long >. Accessed Aug. 20, 2012. doi: 10.1128/ jb.172.9.5035-5043.1990.

DWORKIN, J. et al. Segmental conservation of sapA sequences in type B Campylobacter fetus cells. The Journal of Biological 
Chemistry, v.270, n.25, p.15093-15101, 1995a. Available from: $<$ http://www.jbc.org/content/270/25/15093.full.pdf $>$. Accessed: Jun. 10, 2012. doi: 10.1074/jbc.270.25.15093.

DWORKIN, J. et al. A lipopolysaccharide-binding domain of the Campylobacter fetus S-layer protein resides within the conserved $\mathrm{N}$ terminus of a family of silent and divergent homologs. Journal of Bacteriology, v.177, n.7, p.1734-1741, 1995b. Available from: $<$ https://jb.asm.org/content/177/7/1734.full.pdf $>$. Accessed Aug. 05, 2012. doi: 10.1128/jb.177.7.1734-1741.1995.

ETONSI, M. A. Studies on Arcobacter species, their isolation and pathogenicity. [S.1.]: Heriot-Watt University, United Kingdon, 2013. Available from: <www.ros.hw.ac.uk/bitstream/handle/.../ EtonsiMA_\%0A0813_sls.pdf\%0A>. Accessed: Vov. 21, 2016.

ERICKSON, N. E. N. et al. Evaluation of long-acting oxytetracycline and a commercial monovalent vaccine for the control of Campylobacter fetus subsp. venerealis infectionin beef bulls. Canadian Veterinary Journal, v.58, n.10, p.1051-1058, 2017. Available from: <https://www.ncbi.nlm.nih.gov/pmc/ articles/PMC5603938/>. Accessed: Nov. 10, 2018.

FAGAN, R. P.; FAIRWEATHER, N. F. Biogenesis and functions of bacterial S-layers. Nature Reviews Microbiology, v.12, n.3, p.211-222, 2014. Available from: <https:/www.ncbi.nlm.nih. gov/pubmed/24509785>. Accessed: Feb. 10, 2015. doi: 10.1038/ nrmicro3213.

FERNÁNDEZ, H. et al. Toxigenic and invasive capacities: possible pathogenic mechanisms in Arcobacter cryaerophilus. Memórias do Instituto Oswaldo Cruz, vol.90, n.5, 1995. Available from: <http://www.scielo.br/scielo.php?script=sci_artt ext\&pid=S0074-02761995000500018>. Accessed: Jan. 20, 2015. doi: 10.1590/S0074-02761995000500018.

FIGUEIREDO, J. F. et al. Evaluation of direct fluorescent antibody test for the diagnosis of Bovine Genital Campylobacteriosis. Revista Latinoamericana de Microbiologia, v.44, n.3-4, p.118-123, 2002. Available from: <www.ncbi.nlm.nih.gov/ pubmed/17063594>. Accessed. Nov. 12, 2014.

FOUTS, D. E. et al. Major structural differences and novel potential virulence mechanisms from the genomes of multiple Campylobacter species. PLoS Biology, v.3, n.1, 2005. Available from: <europepmc.org/abstract/med/15660156>. Accessed: Jan 17, 2015. doi: 10.1371/journal.pbio.0030015.

FUJIMOTO, S. et al. Correlation between molecular size of the surface array protein and morphology and antigenicity of the Campylobacter fetus S layer. Infection and Immunity, v.59, n.6, p.2017-2022, 1991. Available from: <www.ncbi.nlm.nih.gov/ pubmed/2037362>. Accessed Sept. 17, 2012.

GARCIA, M. M. et al. Protein shift and antigenic variation in the S-layer of Campylobacter fetus subsp. venerealis during bovine infection accompanied by genomic rearrangement of sapA homologs. Journal of Bacteriology, v.177, n.8, p.1976-1980, 1995. Available from: <jb.asm.org/content/177/8/1976.abstract>. Accessed Aug. 30, 2012. doi: 10.1128/jb.177.8.1976-1980.1995.

GILBERT, M. J. et al. Homologous recombination between genetically divergent Campylobacter fetus lineages supports hostassociated speciation. Genome Biology and Evolution, v.10, n.3, p.716-722, 2018. Available from: < https://www.ncbi.nlm.nih>.
gov/pmc/articles/PMC5830970>. Accessed Jan. 10 2019. doi: 10.1093/gbe/evy048.

GIVENS, M. D. A clinical, evidence-based approach to infectious causes of infertility in beef cattle. Theriogenology, v. 66, p. 648-654, 2006. Available from: <https://www.ncbi.nlm.nih.gov/ pubmed/16725187>. Accessed: Oct. 12, 2012. doi: 10.1016/j. theriogenology.2006.04.021.

GIVENS, M. D. Review: Risks of disease transmission through semen in cattle. Animal, v.12, n.s1, p.s165-s171, 2018. Available from: $\quad<$ https://www.ncbi.nlm.nih.gov/pubmed/29665869>. Accessed: Jan. 10, 2019. doi: 10.1017/S1751731118000708.

GORKIEWICZ, G. et al. A genomic island defines subspeciesspecific virulence features of the host-adapted pathogen Campylobacter fetus subsp. venerealis. Journal of Bacteriology, v.192, n.2, p.502-517, 2010. Available from: <http://jb.asm.org/ content/192/2/502.long >. Accessed: Oct. 17, 2014. doi: 10.1128/ JB.00803-09.

HEWSON P.I. et al. An enzyme-linked immunosorbent assay for the detection of antibodies to C. fetus in bovine vaginal mucus. Research in Veterinary Science, v.38, p.41-45, 1985. Available from: $\quad<$ https://www.ncbi.nlm.nih.gov/pubmed/3975480>. Accessed: Oct. 152014.

HOFFER, M. A. Bovine campylobacteriosis: a review. Canadian Veterinary Journal, v. 22, n. 11, p. 327-330, 1981. Available from: $<$ https://www.ncbi.nlm.nih.gov/pmc/articles/PMC1789996/>. Accessed: Sept. 10, 2012.

HOLT, J. G. et al. Bergey's Manual of Determinative Bacteriology. 9 ed. ed. Philadelphia: Lippincott Williams \& Wilkins, 1994.

HUM, C.; QUINN, D. K. Diagnosis of bovine venereal campylobacteriosis by ELISA. Australian Veterinary Journal, v.71, n.5, p.140-143, 1994. Available from: $<$ https://onlinelibrary. wiley.com/doi/pdf/10.1111/j.1751-0813.1994.tb03367.x>. Accessed: Nov. 20, 2016. doi: 10.1111/j.1751-0813.1994.tb03367.x.

HUM, S. et al. Evaluation of a PCR assay for identification and differentiation of Campylobacter fetus subspecies. BMC microbiology, v.75,n.11, p.827-831, 1997.Available from: $<$ https:// onlinelibrary.wiley.com/doi/full/10.1111/j.1751-0813.1997. tb15665.x>. Accessed: Oct. 26, 2012. doi: 10.1111/j.17510813.1997.tb15665.x.

IRAOLA, G. et al. Distinct Campylobacter fetus lineages adapted as livestock pathogens and human pathobionts in the intestinal microbiota. Nature Communications, v.8, n.1367, p.1-8, 2017. Available from: <https:/www.ncbi.nlm.nih.gov/ pubmed/29118316>. Accessed: Dec. 10, 2017. doi: 10.1038/ s41467-017-01449-9.

JOENS, L. A. et al. Veterinary microbiology and microbial disease. Second ed. Sussex, UK: Blackwell Science Ltd, 2011.

KABEYA, H. et al. Prevalence of Arcobacter species in retail meats and antimicrobial susceptibility of the isolates in Japan. International Journal of Food Microbiology, v.90, n.3, p.303308, 2004. Available from: <www.sciencedirect.com/science/ article/pii/S0168160503003222>. Accessed: Jan. 12, 2015. doi: 10.1016/S0168-1605(03)00322-2. 
KIENESBERGER, S. et al. Comparative genome analysis of Campylobacter fetus subspecies revealed horizontally acquired genetic elements important for virulence and niche specificity. PloS One, v.9, n.1, p.1-13, 2014. Available from: <https://www. ncbi.nlm.nih.gov/pubmed/24416416>. Accessed: Oct. 05, 2014. doi: 10.1371/journal.pone.0085491.

LEAL, D. R. et al. Prevalência da campilobacteriose e da tricomonose genitais bovinas no Distrito Federal e em seu entorno. Revista Brasileira de Reprodução Animal, v.36, n.4, p.256-259, 2012. Available from: <www.cbra.org.br/pages/publicacoes/rbra/ v36n4/p256-259\%20(RB416).pdf >. Accessed: Sept. 10, 2014.

MCCOY, E. C. et al. Superficial antigens of Campylobacter (Vibrio) fetus: characterization of an antiphagocytic component. Infection and Immunity, v.11, n.3, p.517-525, 1975.

MCGOLDRICK, A. et al. Real Time PCR to detect and differentiate Campylobacter fetus subspecies fetus and Campylobacter fetus subspecies venerealis. Journal of Microbiological Methods, v.94, n.3, p.199-204, 2013. Available from: <https://www.ncbi.nlm.nih. gov/pubmed/23811208>. Accessed: Jun. 20 2016. doi: 10.1016/j. mimet.2013.06.014.

MCMILLEN, L. et al. Comparison of culture and a novel 5' Taq nuclease assay for direct detection of Campylobacter fetus subsp. venerealis in clinical specimens from cattle. Journal of Clinical Microbiology, v.44, n.3, p.938-945, 2006. Available from: $<$ https://jcm.asm.org/content/44/3/938.full >. Accessed: Sept. 02, 2015. doi: 10.1128/JCM.44.3.938-945.2006.

MICHI, A. N. et al. A review of sexually transmitted bovine trichomoniasis and campylobacteriosis affecting cattle reproductive health. Theriogenology, v.85, n.5, p.781-791, 2016. Available from: <http://dx.doi.org/10.1016/j.theriogenology.2015.10.037>. Accessed: Jan. 20 2017. doi: 0.1016/j.theriogenology.2015.10.037.

MIRANDA, K. L. Prevalência da infeção por Campylobacter fetus em bovinos de corte do Brasil. [S.1.]: Universidade Federal de Minas Gerais, 2005.

MOOLHUIJZEN, P. M. et al. Genomic analysis of Campylobacter fetus subspecies: Identification of candidate virulence determinants and diagnostic assay targets. BMC Microbiology, v.9, p.1-11, 2009. Available from: <https://bmcmicrobiol.biomedcentral.com/ articles/10.../1471-2180-9-86>. Accessed Dec. 10, 2014. doi $10.1186 / 1471-2180-9-86$

MORAN, A. P. et al. Biological characterization of Campylobacter fetus lipopolysaccharides. FEMS Immunology and Medical Microbiology, v.15, n.1, p.43-50, 1996. Available from: <https:// academic.oup.com/femspd/article/15/1/43/544167>. Accessed: Jun. 10, 2012. doi: 10.1016/0928-8244(96)00043-0

MSHELIA, G.D. et al. Bovine venereal campylobacteriosis: an overview. CAB Reviews: Perspectives in Agriculture, Veterinary Science, Nutrition and Natural Resources, v.2, n.080, p.1-14, 2007. Available from: <http://www.cabi.org/ cabreviews/review/20083052195>. Accessed: Jun. 10 2012. doi: 10.1079/PAVSNNR20072080.

MSHELIA, G. D. et al. Epidemiology of bovine venereal campylobacteriosis: Geographic distribution and recent advances in molecular diagnostic techniques. Reproduction in Domestic Animals, v.45, n.5, 2010. Available from: <https://www.ncbi. nlm.nih.gov/pubmed/19929895>. Accessed Sep. 28 2014. doi: 10.1111/j.1439-0531.2009.01546.x.
MSHELIA, G. D. et al. The prevalence of bovine venereal campylobacteriosis in cattle herds in the Lake Chad basin of Nigeria. Tropical Animal Health and Production, v.44, n.7, p.1487-1489, 2012. Available from: <https://www.ncbi.nlm.nih. gov/pubmed/22318768>. Accessed: Sept. 30, 2014. doi: $10.1007 /$ s11250-012-0092-6

NEILL, S. D. et al. Taxonomic Position of Campylobacter cvyaevophila sp. nov. International Journal of Systematic Bacteriology, v.35, n.3, p.342-356, 1985 . Available from: <https://ijs.microbiologyresearch.org/ content/.../10.../00207713-35-3-342>. Accessed Jan. 15, 2015.

OIE (WORLD ORGANISATION FOR ANIMAL HEALTH). Chapter 2.4.4 Bovine Genital Campylobacteriosis Manual of Diagnostic Tests and Vaccines for Terrestrial Animals. 2017. Available from: $<$ http://www.oie.int/fileadmin/Home/eng/Health standards/tahm/2.04.04_BGC.pdf $>$. Accessed Jan. 20, 2018.

OLIVEIRA, J. M. B. et al. Prevalence and risk factors associated with bovine genital campylobacteriosis and bovine trichomonosis in the state of Pernambuco, Brazil. Tropical Animal Health and Production, v.47, n.3, p. 549-555, 2015. Available from: <https:// www.ncbi.nlm.nih.gov/pubmed/25633914>. Accessed: Oct. 10, 2016. doi: $10.1007 / \mathrm{s} 11250-015-0761-3$.

PEI, Z. et al. Purification and Characterization of a Family of High Molecular weight surface-array protein from Campylobacter fetus. The journal of Biological chemistry, v.263, n.13, p.6416-6420, 1988. Available from: <http://www.jbc.org/content/263/13/6416. long $>$. Accessed: Jun. 15, 2012.

PELLEGRIN, A.O. et al. Bovine Genital Campylobacteriosis in Pantanal, State of Mato Grosso do Sul, Brazil. Revue d'élevage et de médecine vétérinaire des pays tropicaux, v. $55, \mathrm{n} .3, \mathrm{p} .169$ 173, 2002. Available from: <https://revues.cirad.fr/index.php/ REMVT/article/view/9820>. Accessed: Aug. 15, 2014.

PELLEGRIN, A. O. et al. The use of enzyme-linked immunosorbent assay and immunoblotting for the detection of Campylobacter fetus immunoglobulins in the cervico-vaginal mucus of female cattle. Pesquisa Veterinária Brasileira, v.31, n.3, p.247-254, 2011. Available from: <https://remvt.cirad.fr/ revue/notice fr.php?dk $=516885>$. Accessed: Oct. 22,2012 . doi: 10.1590/S0100-736X2011000300011.

PEREZ-PEREZ, G. I. et al. Lipopolysaccharide Structures of Campylobacter fetus. Infection and Immunity, v. 51, n. 1, p. 209-212, 1986. Available from: <https://iai.asm.org/content/ iai/51/1/209.full.pdf>. Accessed: Jun. 10, 2012.

QUINN, P.J. et al. Campylobacter and Helicobacter species. In: Veterinary microbiology and microbial disease. 2. ed. Iowa: Wiley-Blackwell, 2011. Cap.34, p.914-936.

RAY, K. C. et al. Campylobacter fetus sap inversion occurs in the absence of RecA function. Infection and Immunity, v. 68 , n. 10 , p. $5663-5667,2000$. Available from: $<$ https://iai.asm. org/content/68/10/5663>. Accessed: Apr. 17, 2013. 10.1128/ IAI.68.10.5663-5667.2000. doi: 10.1128/IAI.68.10.56635667.2000 .

ROCHA, F. S. et al. Investigação de Campylobacter fetus e Tritrichomonas foetus na mucosa prepucial de touros da região do Médio Paraíba, RJ. Ciência Rural, v.39, n.5, p.1587-1590, 2009. Available from: <https://www.scielo.br/pdf/cr/v39n5/ 
a213cr1128.pdf $>$. Accessed: Nov. 20, 2016. doi: 10.1590/S010384782009005000103 .

SALAMA, S. M. et al. Differentiation of the subspecies of Campylobacter fetus by genomic sizing. International Journal of Systematic Bacteriology, v.42, n.3, p.446-450, 1992. Available from: $\quad<$ https://www.ncbi.nlm.nih.gov/pubmed/1354478>. Accessed: Nov. 5, 2012. doi: 10.1099/00207713-42-3-446.

SAMUELSON, J.D.; WINTER, A. J. Bovine vibriosis: the nature of the carrier state in the bull. The Journal of Infectious Disease, v.116, n.5, p.581-592, 1966. Available from: <https://www.ncbi. nlm.nih.gov/pubmed/5957264>. Accessed: Nov. 20, 2016.

SILVEIRA, C. S. et al. Diagnosis of Bovine Genital Campylobacteriosis in South America. Frontiers in Veterinary Science, v.5, p.1-9, 2018. Available from: <https://www. frontiersin.org/article/10.3389/fvets.2018.00321/full>. Accessed Jan. 10, 2019. doi: 10.3389/fvets.2018.00321.

SKIRROW, S.Z.; BONDURANT, R. H. Bovine trichomoniasis Veterinary Bull, v. 58, p. 591-603, 1988.

SKIRROW, M. B. Diseases due to Campylobacter, Helicobacter and related bacteria. Journal of comparative pathology, v.111 (2), p.113-149, 1994. Available from: <https://www.ncbi.nlm.nih. gov/pubmed/7806700>. Accessed: May, 25, 2014.

SPRENGER, H. et al. So close and yet so far - Molecular microbiology of Campylobacter fetus subspecies. European Journal of Microbiology and Immunology, v.2, n.1, p.66-75, 2012. Available from: <https:// www ncbi.nlm.nih gov/pmc/articles/PMC3933992>. Accessed: Jan. 25, 2013. doi: 10.1556/EuJMI.2.2012.1.10.

SPRENGER, H. et al. Fic proteins of Campylobacter fetus subsp. venerealis form a network of functional toxin-antitoxin systems. Frontiers in Microbiology, v.8, p.1-17, 2017. Available from: $<$ https://www.ncbi.nlm.nih.gov/pubmed/29089929>. Accessed: Jun. 20, 2018. doi: 10.3389/fmicb.2017.01965.

STYNEN, A. P. R. et al. Campilobacteriose genital bovina em rebanhos leiteiros com problemas reprodutivos da microrregião de Varginha - Minas Gerais. Arquivo Brasileiro de Medicina Veterinaria e Zootecnia, v.55, n.6, p.766-769, 2003. Available from: $\quad<$ www.scielo.br/scielo.php?script=sci arttext\&pid $=$ S0102-09352003000600015> . Accessed: Jun. 25, 2013. doi: 10.1590/S0102-09352003000600015.

TIZARD, I. R. Imunidade nas superfícies corpóreas. Imunologia Veterinária. In: . 9.ed. Rio de Janeiro: Elsevier, 2014. Cap. 22, pp. 240-257. (Tradução).

TU, Z.C. et al. Conservation and diversity of sap homologues and their organization among Campylobacter fetus isolates. Infection and Immunity, v.72, n.3, p.1715-1724, 2004. Available from <www.ncbi.nlm.nih.gov/pubmed/14977980>. Accesses: Jun. 10, 2013. doi: 10.1128/IAI.72.3.1715-1724.2004

TU, Z. C. et al. Genetic divergence of Campylobacter fetus strains of mammal and reptile origins. Journal of Clinical Microbiology, v.43, n.7, p.3334-3340, 2005. Available from: <https://www.ncbi. nlm.nih.gov/pubmed/16000457>. Accessed: Sept. 30, 2012. doi: 10.1128/JCM.43.7.3334-3340.2005.

VAN BERGEN, M. A. P. et al. Global detection and identification of Campylobacter fetus subsp. venerealis. Revue Scientifique
Et Technique-Office International Des Epizooties, v.24, n.3, p.1017-1026, 2005a. Available from: <https://www.ncbi.nlm.nih. gov/pubmed/16642772>. Accessed: Oct. 05, 2015. doi: 10.20506/ rst.24.3.1629.

VAN BERGEN, M. A. P. et al. Amplified fragment length polymorphism based identification of genetic markers and novel PCR assay for differentiation of Campylobacter fetus subspecies. Journal of Medical Microbiology, v.54, n.12, p.1217-1224, 2005b. Available from: <https://www.ncbi.nlm.nih.gov/ pubmed $/ \% 0 \mathrm{~A} 16278437 \% 0 \mathrm{~A}>$. Accessed: Oct. 05,2015 . doi: 10.1099/jmm.0.46186-0.

VAN BERGEN, M.A.P. et al. Clonal Nature of Campylobacter fetus as Defined by Multilocus Sequence Typing. Society, v.43, n.12, p.5888-5898, 2005c. Available from: <https://www.ncbi. nlm.nih.gov/pubmed/16333072>. Accessed: Jan. 20, 2016. doi: 10.1128/JCM.43.12.5888

VAN DER GRAAF-VAN BLOOIS, L. et al. Evaluation of molecular assays for identification Campylobacter fetus species and subspecies and development of a $C$. fetus specific real-time PCR assay. Journal of Microbiological Methods, v.95, n.1, p.93-97, 2013. Available from: <https://www.ncbi.nlm.nih.gov/ pubmed/23810970>. Accessed: Feb. 10, 2015. doi: 10.1016/j. mimet.2013.06.005.

VAN DER GRAAF-VAN BLOOIS, L. et al. Inconsistency of phenotypic and genomic characteristics of Campylobacter fetus subspecies requires reevaluation of current diagnostics. Journal of Clinical Microbiology, v.52, n.12, p.4183-418, 2014. Available from:<https://www.ncbi.nlm.nih.gov/pubmed/25232170>. Accessed: Jun. 20, 2015. doi: 10.1128/JCM.01837-14.

VAN DER GRAAF-VAN BLOOIS, L. et al. Campylobacter fetus subspecies contain conserved type IV secretion systems on multiple genomic islands and plasmids. PLoS ONE, v. 11, n. 4, p. 1-15, 2016. Available from: <http://journals.plos.org/plosone/ article?id=10.1371/journal.pone. $0152832>$. Accessed: May, 30, 2017. doi: 10.1371/journal.pone.0152832.

VARGAS, A. et al. Campylobacter fetus subspecies venerealis surface array protein from bovine isolates in Brazil. Current Microbiology, v.45, n.2, p.111-114, 2002. Available from: <www. ncbi.nlm.nih.gov/pubmed/12070688>. Accessed: Oct. 05, 2012. doi: 10.1007/s00284-001-0090-9.

VASQUEZ, L. A. et al. Bovine genital campylobacteriosis (vibriosis): vaccination of experimentally infected bulls. American Journal of Veterinary Research, v.44, p.1553-1557, 1983.

VÉRON, M. , CHATELAIN, R. Taxonomic Study of the Genus Campylobacter Sebald and Véron and Designation of the Neotype Strain for the Type Species, Campylobacter fetus (Smith and Taylor) Sebald and Veron, v.23, n.2, p.122-134, 1973. Available from: <https://ijs.microbiologyresearch.org/content/ journal/ijsem/10.1099/00207713-23-2-122>. Accessed: Jun. 20, 2012. doi: $10.1099 / 00207713-23-2-122$.

WAGENAAR, J. A. et al. Comparative Study Using Amplified Fragment Length Polymorphism Fingerprinting, PCR Genotyping, and Phenotyping To Differentiate Campylobacter fetus Strains Isolated from Animals. Journal of Clinical Microbiology, v.39, n.6, p.2283-2286, 2001. Available from: <https://www.ncbi. nlm.nih.gov/pubmed/11376071>. Accessed: Nov. 10, 2012. doi: 10.1128/JCM.39.6.2283-2286.2001. 
WANG, E. et al. Shift in S-layer protein expression responsible for antigenic variation in Campylobacter fetus. Journal of Bacteriology, v.175, n.16, p.4979-4984, 1993. Available from: $<$ https://jb.asm.org/content/175/16/4979.abstract>. Accessed: Sept. 20, 2012. doi: 10.1128/jb.175.16.4979-4984.1993.

WANG, G. et al. Colony Multiplex PCR Assay for Identification and Differentiation of Campylobacter jejuni, C. coli, C. lari, C. upsaliensis and C. fetus subsp. fetus. Journal of Clinical Microbiology, v.40, n.12, p.4744-4747, 2002. Available from: $<$ https://www.ncbi.nlm.nih.gov/pmc/articles/PMC154608/ pdf/0600.pdf>. Accessed: Oct. 05, 2013. doi: 10.1128/ JCM.40.12.4744

WANG, C. et al. Complete genome sequence of Campylobacter fetus subsp. testudinum strain Pet-3, isolated from a lizard (Hydrosaurus pustulatus). Genome Announcements, v.3, n.1, p.9-10, 2015. Available from: <https:/www.ncbi.nlm.nih.gov/ pmc/articles/PMC4335325>. Accessed: Jan. 25, 2018. doi: 10.1128/genomeA.01420-14.
WINTER, A. J. et al. Microcapsule of Campylobacter fetus: Chemical and physical characterization. Infection and Immunity, v.22, n.3, p.963-971, 1978.

YAEGER, M. J.; HOLLERY, L. D. Bacterial Causes of Bovine Infertility and Abortion. In: YOUNGQUIST, R. S. \& THRELFALL, W. R. (Org.). Current Therapy in Large Animal Theriogenology. second edition, ed. EUA: Saunders Elsevier, 2007, p. 391-393

ZHAO, H. et al. Development and evaluation of an indirect enzymelinked immunosorbent assay for the detection of antibodies against Campylobacter fetus in cattle. Research in Veterinary Science, v.88, n.3, p.446-451, 2010. Available from: <http://linkinghub. elsevier.com/retrieve/pii/S0034528809002690>. Accessed: Jan. 20, 2013. doi: 10.1016/j.rvsc.2009.11.013.

ZIECH, R. E. et al. Campylobacter fetus in cattle from Rio Grande do Sul state, Brazil, Ciencia Rural, v.44, n.1, p.141-146, 2014 Available from: <www.scielo.br/scielo.php?script=sci_arttext\&p id $=$ S0103-84782014000100023 $>$. Accessed: Dec. 17, 2014. doi: 10.1590/S0103-84782014000100023. 